\title{
Discovering the original tech stocks
}

\author{
Michelle Gittelman
}

\author{
From Alchemy to IPO: \\ The Business of Biotechnology \\ Cynthia Robbins-Roth \\ 2000 Perseus Publishing, \\ 256 pages, \$25 hardcover
}

In a sense, scientists have it easy. To get their point across, they don't have to make it up as they go along. There are rules, procedures, and standards-falsifiability and replicability among the most important-designed to allow others to judge the merits of their scientific claims.

When it comes to selling a new business idea, the process is a lot murkier. Resources need to be mobilized, people need to be convinced to part with their money, employees need to be recruited, advisors and supporters need to be lined up. But in a new or emerging business sector there are no established and long-cherished metrics, as there are in science, on which to base one's claims. Instead, the task of selling a new business idea is open to anyone with the fervor (or guile) necessary to convince outsiders that this is a worthy place to spend their attention, money, and time.

From Alchemy to IPO is about selling the business of biotech. It is pitched as a primer for investors new to the industry but savvy to the world of investing in high-tech stocks. The biotech sector has the distinction of having pioneered the business model of the New Economy, whereby firms spend large sums of other people's money and may never show a profit for it. Biotech firms have been doing this since the early 1980 s, and during many lean years struggled to raise investor interest in their mission to bring revolutionary science to a commercial marketplace. In these days of giddy stock market returns, the biotech sector has found new appeal among investors who have cut their teeth on Internet startups. Now, educated on the new business model by dot-coms, they are looking to invest in something new. This book is ready for them, with a quick overview of biotech's history, its major players, the ins and outs of product development, financing modes, and pointers for a successful investment strategy.

Michelle Gittelman is assistant professor of management, New York University Stern School of Business (mgittelm@stern.nyu.edu).

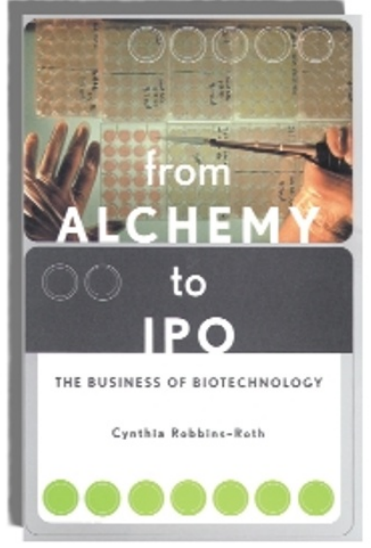

This raises the question: can you teach an outsider to invest in a very complex business that is run by insiders? To the extent that this is possible, the book does a good job, and largely succeeds in laying out major guideposts for the uninitiated. The author, a former scientist and now an industry consultant, knows the business, and she knows the science. Apart from the occasional lapse into rousing cheers ("Biotechnology is poised to explode in the next decade, in products and in profits") and page-filling tributes to the awesomeness of it all (an entire chapter is a speech by NASA's chief on the potential of biotechnology for space exploration), readers are in the hands of a reliable and careful instructor. She duly points out the risks inherent in drug discovery, and doesn't neglect to discuss the abject failures along with the breathtaking successes. Although she never quite spells out just how frightening the financials can be in this industry, she doesn't gloss over the fact that investing in biotech, despite a history of positive returns, is not for the faint of heart. Readers new to the industry will be grateful for the introduction to its basic vocabulary, from the business potential of a protein-binding receptor to the scientific import of stock options.

The book is written with the flavor of a text; the author carefully avoids journalistic editorializing or academic pondering on deeper meanings. But she appears to be more interested in probing the issues than she lets on, and several intriguing nuggets of insight can't help but leak through the sometimes rather dry descriptions. The degree to which financing and technology strategy are intertwined is a theme that recurs throughout the book. One of life's basic lessons, painfully familiar to many adolescents, is that when your survival depends on other people's money, they have a powerful say over what you can do. The biotechnology industry has never fully escaped this. Shifts in the technological focus of the industry-from its early promises of new cancer drugs to the current wave of firms based on data mining and biochips-are as much a reflection of the clout of the investment community as they are of the landscape of scientific opportunity. The story of Amgen's early days, presented in the first part of the book, tells how the company's broad-based research program reflected the disparate needs of investors in the oil, chemicals, and agriculture businesses. Amgen succeeded, largely through lucky draws that led to two unexpected blockbusters, in becoming into a large integrated pharmaceutical firm. But " $[t]$ oday, you would never find a funded company this broadly spread." The author laments that few investors are "visionary," unwilling to pay for far-reaching projects or a broad-based technology strategy: instead, "risk reduction... has led to a spate of 'tool' companies ... and the infamous 'accelerated commercialization' in which research companies tried to in-license niche products rejected by other companies in the hopes of generating product revenues much earlier in their evolution." This is not the kind of information an investor can use to pick up a phone and call a broker, but it hints at the kind of knowledge that makes for a deeper understanding of what drives shifts in the competitive and technological landscape.

Without more emphasis on the underlying dynamics and relationships that drive the industry, the book remains a handbook for investors new to biotech. Readers of this publication won't gain much from the basic science tutorials, but might find useful the nutsand-bolts information on how new companies are built out of the science, both financially and managerially, although intellectual property issues are strangely missing here. But perhaps the best information for wouldbe investors is found in the first part of the book, which provides brief histories of major biotechnology firms and their founders (for an excellent and more complete history of the industry, readers can still turn to Martin Kenney's Biotechnology: The UniversityIndustry Complex, Yale University Press, 1986). To the extent that these stories give readers an appreciation for the importance of that illusive quantity-social capital-in creating value in this industry, they provide the best insider information that a handbook can hope to convey. 